\title{
The Effect of Economic Growth, Microfinance Institution, and Micro and Small Enterprises to Income Inequality in South Sulawesi
}

\author{
Anas Iswanto Anwar ${ }^{1}$ and Muhammad Agung Ady Mangilep ${ }^{2}$ \\ ${ }^{1}$ Hasanuddin University, Indonesia, e-mail: aianwar@,fe.unhas.ac.id \\ ${ }^{2}$ Hasanuddin University, Indonesia, e-mail: agungam@fe.unhas.ac.id
}

\begin{abstract}
This study aims to determine the relationship of economic growth, small banks, and small enterprises on income inequality in South Sulawesi. Secondary data from 2005 to 2016 are used on the descriptive quantitative approach which is analyzed by a multiple linear regression analysis. The results showed that the economic growth, the amount of credit disbursed by small banks and the number of small enterprises' labors have significant impacts on the income equalization.
\end{abstract}

Keywords: economic growth, small banks, small enterprises, income inequality

\section{Introduction}

Growing inequality is one of important problems on a developing country including Indonesia. Narrowing a gap of income distribution has become one of government's main concerns.

An economic development requires a participation of financial institution which needs available fund. Therefore, banking companies are indispensable and become an important joint of the national economy. With a healthy banking condition, efficiency and benefit for the economy becomes the key to success in maintaining the sustainability of economic development.

Based on the Act Number 10 of 1998, the small bank is a bank that conducts all banking activities but inter-banks payments, based on either conventional or sharia practices. A small bank can be formed as a limited liability company, a regional enterprise, or a cooperative.

Small banks have a strategic role on Indonesian economy especially on encouraging the development of small enterprises. Those banks act as creators of business and equity of employment by serving small businesses and communities in rural areas.

Small enterprises are business units whose sales below Rp 100 million. The capital aspect is one of fundamental problems of small enterprises. Those enterprises have a limited access to financial resources provided by commercial banks (Wijono, 2005, Harsono 2010). Small bank, as a main actor of a country development, can be one solution of small enterprises' problems which would contribute on national growth and welfare. Based on the above explanation implies a linkage among income inequality, small banks, small enterprises and economic growth.

Earlier studies on income inequality have found several factors that contribute significantly to income inequality. Most studies found education to be an important factor that creates wider income gap between the poor and the rich (Contreras et al. 2009; De Silva and Sumarto 2013; and Sapelli 2011). Some studies also find that access to finance matters in explaining income inequality (Wan and Zhou 2004; Bae, Han, and Son 2012).

According to the more recent study by the World Bank (2016), there are several main causes of income inequality in Indonesia: (i) unequal opportunity, (ii) unequal jobs, (iii) high wealth concentration, and (iv) low resiliency.

Income inequality is a condition in which the distribution of income received by society is uneven. Inequality is determined by the level of development, ethnic heterogeneity, inequality also associated with dictatorships and governments that fail to respect property rights (Glaeser, 2006). Alesina and Rodrik (1994) argue that income inequality will hamper growth. This is because inequality leads to a revenue redistribution policy that would be expensive.

Inequality of income in society can be classified as low, medium or high inequality. This grouping corresponds to the size of inequality used. The Gini index value in countries with high inequality 
ranges from 0.50 to 0.70 , whereas for countries whose distribution is relatively evenly distributed, the value is between 0.20 to 0.35 (Todaro and Smith, 2006).

The concept of microfinance has influenced by two major schools; the Institutional school and the Welfares school. Institutional school focuses on developing a financially sustainable institution that is expected to serve the poor. A foundation of such approach is to provide financial services to poor at an affordable cost. Numerous large-scale, profit seeking microfinance organizations come under this approach that provides high quality financial services to the poor.

BPR is a micro finance institution that has a strategic role in providing financial services to MSEs, because of its close strategic position with the community, simpler public service procedures and more personal approach. This can be used as one of the drivers of the increasing number of MSEs in South Sulawesi.

MSEs definitions can be broadly categorized into two, "economic" and "statistical" definitions. Under the economic definition, a firm is regarded as small if it meets the following three criteria: (1) it has a relatively small share of their market place; (2) it is managed by owners, or part owners, in a personalized way and not through the medium of a formalized management structure; and (3) it is independent in that it is not part of a larger enterprise.

The "statistical" definition, on the other hand, is used in three main areas: (1) quantifying the size of the small firm sector and its contribution to GDP, employment and exports; (2) comparing the extent to which the small firm sector's economic contribution has changed over time; and (3) in a crosscountry comparison of the small firms' economic contribution.

One way to increase economic growth is to move the economy that involves many small people such as the empowerment of MSEs. Prasetyo (2008) writes in the economy is its ability in the absorption of manpower with a considerable amount compared to other types of business. The absorption of manpower through this MSEs will increase the income especially the poor so that it can meet the minimum requirement which means out of the poor condition.

The value of the MSEs sector is recognized in economies world-wide, irrespective of the economy's developmental stage. The contribution towards growth, job creation and social progress is valued highly, and small business is regarded as an essential element in a successful formula for achieving economic growth

Economic growth is an increase in the capacity of an economy to produce goods and services, compared from one period to another. It can be measured in nominal or real terms, the latter of which is adjusted for inflation. Traditionally, aggregate economic growth is measured in terms of gross national product (GNP) or gross domestic product (GDP), although alternative metrics are sometimes used.

According Sukirno in Ruliansyah (2013) that economic growth is defined as the development of activities in the economy that causes goods and services produced in society increases and the welfare of society increases

\section{Research Methodology}

This research is quantitative research with the method that will be used is descriptive quantitative method through multiple linear regression analysis of Ordinary Least Square (OLS), with the following formula (Gujarati, 2010):

$\mathrm{LnY}=\mathrm{Ln} \alpha+\beta 1 \operatorname{LnX} 1+\beta 2 \operatorname{LnX} 2+\beta 3 \operatorname{LnX} 3$

The model is described as follows:

Ln Y: Income Inequality (\%)

Ln X1: Economic Growth (\%)

Ln X2: MFIs' credit (Rp)

Ln X3: MSEs' labor (person)

$\alpha$ : intercept

$\beta i$ : regression coefficient 
Result and Discussion

Model 1: OLS, using observations 1-12

Dependent variable: GINIRATIO

\begin{tabular}{|l|l|l|l|l|}
\hline & \multicolumn{1}{|c|}{ coefficient } & \multicolumn{1}{c|}{ std. error } & \multicolumn{1}{c|}{ t-ratio } & \multicolumn{1}{c|}{-value } \\
\hline const & 0.464325 & 0.155501 & 2.986 & $0.0174 * *$ \\
\hline Economic growth & 0.00876299 & 0.00458498 & 1.911 & $0.0924^{*}$ \\
\hline Micro Institution & $9.42132 \mathrm{e}-11$ & $4.52191 \mathrm{e}-11$ & 2.083 & $0.0707 *$ \\
\hline MSEs & $-2.17581 \mathrm{e}-07$ & $2.09370 \mathrm{e}-07$ & -1.039 & 0.3291 \\
\hline Mean dependent var & 0.393500 & S.D. dependent var & 0.030935 & \\
\hline Sum squared resid & 0.001297 & S.E. of regression & 0.012731 & \\
\hline R-squared & 0.876834 & Adjusted R-squared & 0.830646 & \\
\hline F $(3,8)$ & 18.98425 & P-value(F) & 0.000538 & \\
\hline Log-likelihood & 37.77036 & Akaike criterion & -67.54072 & \\
\hline Schwarz criterion & -65.60109 & Hannan-Quinn & -68.25884 & \\
\hline
\end{tabular}

The above table shows the value of $\mathrm{R}$ square $(\mathrm{R} 2)=0.821$ means that $82.10 \%$ of dependent variable Inequality Income (Y) is explained by the independent variable Economic growth (X1), microfinance institution (X2) and micro and small enterprises (X3) and the remaining $17.90 \%$ is explained by other variables outside of the model.

In that model there are 3 (three) free variable coefficients and 1 (one) dependent variable, with the result of calculation (Unstandardized) as follows:

a. Constant $=0.4643$, meaning that if there is no economic growth, microfinance institution, and micro and small enterprises, then the inequality income in South Sulawesi will increase $0.4643 \%$.

b. Economic Growth $=0,0088$, meaning if there is addition of economic growth equal to $1 \%$, hence will cause Income Inequality increases to $0.008 \%$ ceteris paribus.

c. Microfinance institution $=9,4213$, meaning if there is addition of credit equal to Rp. 1 then it will cause Income Inequality has increased by $9,421 \%$ ceteris paribus.

d. Micro and small enterprises $=-2,1758$, meaning if there is addition of 1 person MSEs entrepreneurs, it will cause Income Inequality down by $2.176 \%$ ceteris paribus.

From result of regression analysis obtained result that partially independent variable economic growth (X1) and microfinance institution (X2) have positive and significant effect to Income Inequality in South Sulawesi, while variable number of MSEs (X3) have negative and insignificant effect. This is in line with Alkadri (2006), Wibisono (2001), Pancawati (2000), Yuliarmi (2008), Wahyuni (2004) and Chemingui and Arsyad (2003). Simultaneously or simultaneously the three independent variables, namely economic growth (X1), microfinance institution (X2) and micro and small enterprises (X3) have a significant effect on Income Inequality in South Sulawesi.

From the results of this analysis shows that the actual Income Inequality in South Sulawesi is still very dependent on the amount of credit disbursed by BPR and the number of MSEs, because with the increasing number of UMKM entrepreneurs and the amount of credit disbursed by BPR can be used as capital to drive the economy in South Sulawesi. This is in accordance with the results of research conducted by: Yusuf (2005), Suhartini (2014), Anas (2016).

Increased economic growth should also be followed by inequality income, but the results of this study indicate different things caused by economic growth that occurred in South Sulawesi is classified as not qualified, causing inequality income is also greater. 


\section{Conclusion}

Based on the results of this study, it can be concluded that: (1) an increasing economic growth will decrease income inequality, (2) the increasing amount of credit disbursed by BPR will decrease income inequality, and (3) an increasing number of MSEs will decrease income inequality.

\section{References}

Anwar, Anas Iswanto. 2016. Analisis Pengaruh Financial Inclusion Terhadap Pertumbuhan Ekonomi dan Kemiskinan di Indonesia Tahun 2005-2013. Disertasi Program Doktor Ilmu Ekonomi, FEB-Unhas.

Arsyad, Lincolin. 2004. Ekonomi Pembangunan dan Perencanaan Pembangunan. Edisi keempat. STIE YKPN. Yogyakarta.

Badan Pusat Statistik Propinsi Sulawesi Selatan. 2016. Provinsi Sulawesi Selatan Dalam Angka 2016.

Bae, K., D. Han, and H. Sohn. 2012. Importance of Access to Finance in Reducing Income Inequality and Poverty Level. International Review of Public Administration 17 (1): 55-77.

Contreras, D., O. Larranaga, E. Puentes, and T. Rau. 2009. Evidence for Inequality of Opportunities. A Cohort Analysis for Chile. Santiago.

de Silva, I. and S. Sumarto. 2013. Poverty-growth inequality triangle: the case of Indonesia. TNP2K Working Paper. http://www.tnp2k.go.id/images/uploads/ downloads/WP4PovertyTriangle(1).pdf (accessed 30 January 2017).

Gujarati, Damodar N. 2001. Basic Econometric. 3rd ed, McGraw Hill International Edition. New York.

Jhingan, M.L. 2002. Ekonomi Pembangunan dan Perencanaan. cetakan kesembilan. diterjemahkan oleh D. Guritno. PT. Raja Grafindo Persada Jakarta.

Mankiw, Gregory. N. 2003. Macroeconomics. 5rd ed, by Worth Publishers New York and Basingstokes. Terjemahan. Penerbit Erlangga Surabaya.

Nasir, Moh. 1999. Metode Penelitian, Cetakan Ketiga, Ghalia Indonesia Jakarta.

Sapelli, C. 2011. A cohort analysis of the income distribution in Chile. Estudios de economía 38 (1): 223-242.

Suhartini, Atik Mar'atis dan Yuta, Ropika. 2014. Keterkaitan Lembaga Keuangan Mikro (LKM), Usaha Mikro dan Kecil (UMK) serta Kemiskinan di Indonesia Tahun 2012. Jurnal Ekonomi Kuantitatif Terapan, Vol. 7, No. 2. Agustus 2014.

Sukirno, Sadono. 2005. Ekonomi Pembangunan, Proses, Masalah dan Dasar Kebijaksanaan. LPFEUI Jakarta.

Todaro, Michael P. 2000. Ekonomi Pembangunan. diterjemahkan oleh Haris Munandar. Edisi kelima. Bumi Aksara Jakarta.

Wahyuni, Heni. 2004. The Role of Government in Economic Growth: Evidence from Asia and Pacific Countries. Journal of Indonesian Economy and Business. 19(1): 71-81.

Wan, G. and Z. Zhou. 2004. Income Inequality in Rural China: Regression-based Decomposition Using Household Data (No. 2004/51). WIDER Discussion Papers/World Institute for Development

Wibisono, Yusuf. 2005. Sumber-Sumber Pertumbuhan Ekonomi Regional: Studi Empiris Antar Propinsi di Indonesia. Jurnal Ekonomi dan Pembangunan Indonesia. 5(2): 224-235.

Wicaksono, Eko; Amir, Hidayat; and Nugroho, Anda. The Sources of Income Inequality in Indonesia: A Regression-Based Inequality Decomposition, ADBI Working Paper Series, No. 667 February 2017. 